Sains Malaysiana 49(12)(2020): 2913-2925

http://dx.doi.org/10.17576/jsm-2020-4912-04

\title{
Rapid ESKAPE Pathogens Detection Method using Tapered Dielectrophoresis Electrodes via Crossover Frequency Analysis
}

(Kaedah Pengesanan Pantas Patogen ESKAPE menggunakan Elektrod Dielektroforesis Tirus melalui Analisis Frekuensi Pindah Silang)

\author{
Muhammad Khairulanwar Abdul Rahim*, Nur Mas Ayu Jamaludin, Jacinta Santhanam, Azrul Azlan \\ HAMZAH \& MUHAMAD RAMDZAN BUYONG
}

\begin{abstract}
This paper introduces the versatile of an electrokinetic technique by using the non-uniform electric field for dielectrophoresis (DEP) application. This technique is defined as electromicrofluidics. The potential application for portable and real time detection method of Enterococcus faecium (EF), Staphylococcus aureus (SA), Klebsiella pneumoniae (KP), Acinetobacter baumannii (AB), Pseudomonas aeruginosa (PA) and Enterobacter aerogenes (EA), which are the (ESKAPE) bacteria. The MATLAB analytical modelling was used in simulating the polarisation factor and velocities of bacteria based on Clausius-Mossotti factor (CMF). The validation of CMF simulation through the DEP experimental can be quantified based on the response of alternating current (AC) voltage applied using 6 voltage peak to peak $\left(V_{p-p}\right)$ to their input frequencies from 100 to $15000 \mathrm{kHz}$. The droplet method was deployed to place properly 0.2 $\mu L$ of sample onto DEP microelectrode. The velocities and crossover frequency $\left(f_{x o}\right)$ ranges of bacteria were determined through bacteria trajectory in specific time interval monitored by microscope attached with eyepiece camera. The applied range of input frequencies from 100 to $15000 \mathrm{kHz}$ at $6\left(V_{p-p}\right)$ for each bacteria were successfully identified the unique ranges of frequencies response for detection application. The advantages of this works are selective with rapid capability for multidrug resistant (MDR) bacteria detection application.
\end{abstract}

Keywords: Crossover frequency $\left(f_{x o}\right)$; dielectrophoresis; ESKAPE bacteria

\section{ABSTRAK}

Makalah ini memperkenalkan satu teknik elektrokinetik yang menggunakan medan elektrik secara tidak seragam iaitu dielektroforesis (DEP). Teknik ini ditakrifkan sebagai elektromikrofluidik. Berpotensi bagi aplikasi secara mudah alih dan pada masa nyata untuk pengesanan Enterococcus faecium (EF), Staphylococcus aureus (SA), Klebsiella pneumoniae (KP), Acinetobacter baumannii (AB), Pseudomonas aeruginosa (PA) dan Enterobacter a erogenes (EA) yang merupakan bakteria (ESKAPE) Pemodelan analitik MATLAB digunakan dalam mensimulasi faktor polarisasi dan halaju bakteria berdasarkan faktor Clasius-Mossotti (CMF). Pengesahan simulasi CMF melalui uji kaji DEP dapat dihitung berdasarkan tindak balas voltan arus ulang alik (AC) yang menggunakan 6 volt puncak ke puncak ( $\left.V_{p-p}\right)$ terhadap frekuensi inputnya dari 100 sehingga $15000 \mathrm{kHz}$. Kaedah titisan digunakan untuk menempatkan $0.2 \mu \mathrm{L}$ sampel ke atas permukaan mikroelektrod DEP dengan tepat. Julat halaju dan frekuensi pindah silang $\left(f_{x o}\right)$ bakteria ditentukan melalui lintasan bakteria dalam selang waktu tertentu yang dipantau oleh mikroskop yang diintegrasikan bersama kamera. Julat frekuensi input yang dikenakan terhadap ESKAPE bakteria dari 100 hingga $15000 \mathrm{kHz}$ pada 6 ( $\left.\mathrm{V}_{p-p}\right)$ untuk setiap bakteria berjaya dikenal pasti julat frekuensi pindah silang uniknya sebagai pengesanan. Hasil analisis, kelebihan penyelidikan ini adalah kebolehan secara selektif dengan kemampuan pantas untuk aplikasi pengesanan bakteria yang rentan kepada antibiotik (MDR), ESKAPE Ini membolehkan aplikasi pengesan bakteria ini dilakukan secara tepat dengan menggunakan teknik yang mudah pada masa hadapan.

Kata kunci: Dielektroforesis; ESKAPE bakteria; frekuensi pindah silang $\left(f_{x o}\right)$

\section{INTRODUCTION}

Over 40 years ago, dielectrophoresis (DEP) technology related to electrokinetic mechanism were explored. Recently, enhancement with integrated microelectrofluidic applications was established. The DEP microelectrofluidic solution is used for the detection, separation, and isolation of biology particles (Buyong et al. 2019; Yunus et al. 2019), bacteria (Rahim et al. 2018), red blood cells (RBC) (Abd Samad et al. 2019; Yunus et al. 2018), and 
cancer cells (Jamaludin et al. 2018). Advantages, it is a contactless, simple, free contamination and clean method that uses non-uniform electric field expose to sample without additional of labelling material (Buyong et al. 2019; Cha et al. 2019; D'Amico et al. 2017; Kikkeri et al. 2018; Mohammad et al. 2017; Sadeghian et al. 2017; Shirmohammadli \& Manavizadeh 2018; Siebman 2018).

This study was focused on DEP mechanism implementation for bacteria detection of the Enterococcus faecium (EF), Staphylococcus aureus (SA), Klebsiella pneumonia (KP), Acinetobacter baumannii (AB), Pseudomonas aeruginosa (PA) and Enterobacter aerogenes $(E A)$. These bacteria are commonly associated to multidrug resistance (MDR) species (Brooks et al. 2018; González-Bello 2017; Karlowsky et al. 2017; Phoon et al. 2018; Rani et al. 2017; Santajit \& Indrawattama 2016). The ESKAPE bacteria are divide into two groups; gram-positive and gram-negative. The gram-positive group includes $E F$ and $S A$ species. The $E F$ species have round shape in pairs or chain arrangement. The SA species also have a round shape, but with grape-like cluster arrangement. The gram-negative group includes $K P$, $A B, P A$ and $E A$. The $K P$ is encapsulated and rod in shape. Meanwhile, $A B$ has a rod shape and sometimes round when entering growing stages. The $P A$ is rod in shape. Whereas the $E A$ is gram-negative, rod in shape, and sometimes encapsulated.

Various methods have been developed by scientists for detecting bacteria produced by bacteria especially antiresistance multidrug bacteria like ESKAPE. Additionally, there are several methods to rapidly detect ESKAPE bacteria. The current method for detecting ESKAPE bacteria is time consuming and complex (Santajit \& Indrawattama
2016). The latest ESKAPE detection methods include mass spectrometric analysis (Leung et al. 2017), nitroreductasetriggered fluorescence turn-on probe (NTR) (Xu et al. 2017), T2 bacteria magnetic resonance assay (De Angelis et al. 2018) and isothermal DNA-based assays in a portable degas-actuated microfluidic diagnostic assay platform (Renner et al. 2017). All detection techniques require various steps prior to testing the samples. The Leung et al. (2017) method used the mass spectrometric analysis requires added chemical named ammonium-isobutyrate to isolate ESKAPE bacteria from pure culture or biological specimen to their whole cell lipids. This chemical is important in identifying the unique 'signature ions' of each ESKAPE species from their lipid cells by mass spectrometer. Xu et al. (2017) used the NTR technique which also requires additional chemical known as astris buffer solution at $\mathrm{pH} 7.4$, containing $500 \mathrm{mM} \mathrm{NADH}$ for identifying all ESKAPE species with fluorescence analysis (FL analysis). Similar to these, Renner et al. (2017) technique also uses FL analysis, but the difference is that the method uses embedded electronics device with electronics circuit, battery, LEDs, and microfluidic channel. Different LEDs produce different intensity of fluorescence effect. This Renner et al. (2017) technique also uses FL intensity to identify ESKAPE bacteria, but it requires a reagent as additional chemical, which is magnesium acetate (MgOAc), during the sample loading step. De Angelis et al. (2018) technique is slightly different than the other methods discussed since it uses magnetic field to identify ESKAPE bacteria, but needs additional materials like superparamagnetic particles through the binding of attached species-specific probes.
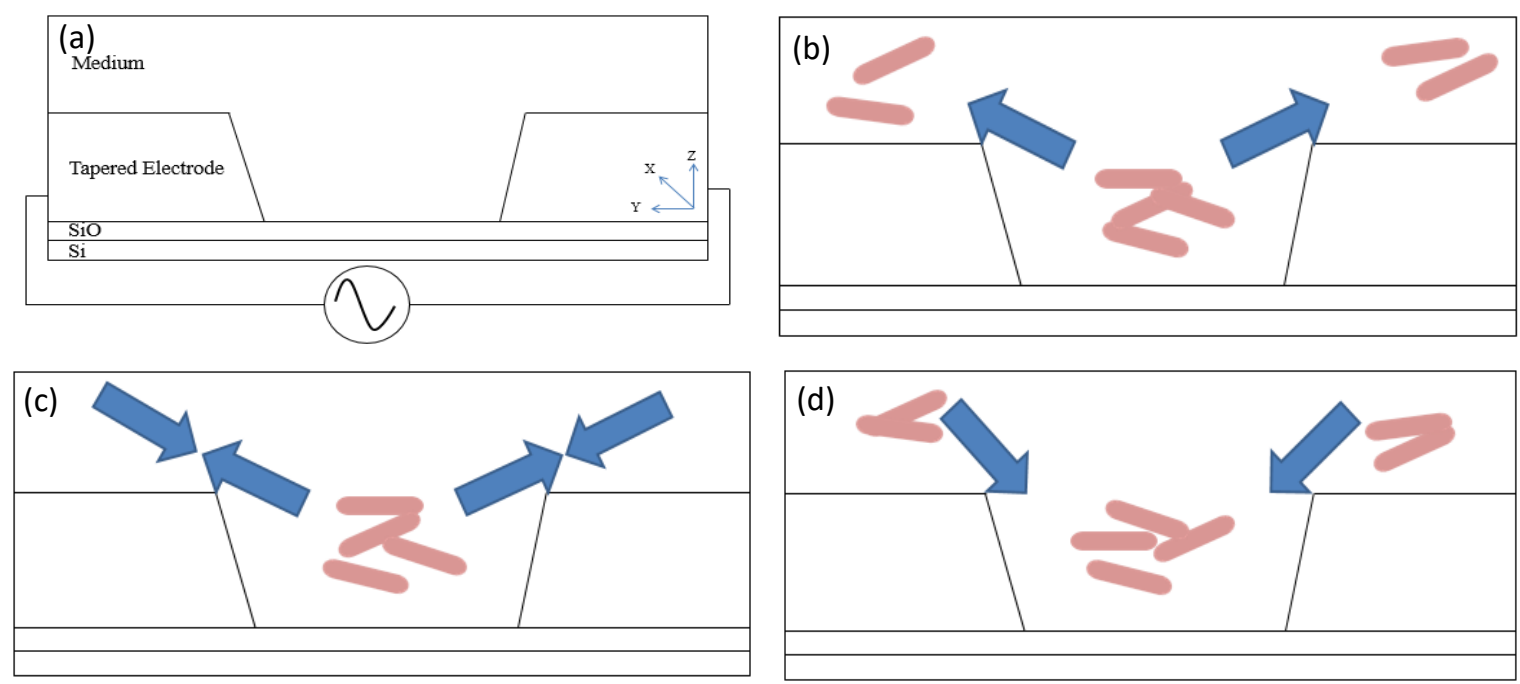

FIGURE 1. a) Schematic of DEP microelectrode configuration and blue arrows of lateral and vertical $\mathrm{F}_{\mathrm{DEP}}$, b) The ESKAPE bacteria, rod shaped is laterally attracted to top surface of DEP microelectrode when $\mathrm{P}_{\mathrm{DEP}}$ frequency applied, c) No movement of ESKAPE bacteria when applying frequency $\mathrm{P}_{\mathrm{DEP}}$ equivalent to $\mathrm{N}_{\mathrm{DEP}}$ at $\mathrm{f}_{\mathrm{xo}}$ value, and d) The ESKAPE bacteria is vertically repelled from the top surface of DEP microelectrode to center of channel when $\mathrm{N}_{\text {DEP }}$ frequency applied 
The introduction of DEP technique is simple and clean method compared to other method. Not require any added chemical or materials, besides being a contactless method. Furthermore, it is able to give a rapid real time detection and easy to use. The novelty of the proposed technique is using tapered DEP microelectrode. Lateral and vertical DEP forces $\left(\mathrm{F}_{\mathrm{DEP}}\right)$ were created by tapered DEP microelectrode, which made it easier to produce the isolation and selection of targeted ESKAPE bacteria. Thus, it is a potentially alternative solution for ESKAPE detection that is rapid and in real time. Figure 1 illustrates the schematic of DEP experimental and DEP responses positive DEP $\left(\mathrm{P}_{\mathrm{DEP}}\right)$, negative DEP $\left(\mathrm{N}_{\mathrm{DEP}}\right)$, and crossover frequency $\left(\mathrm{f}_{\mathrm{xo}}\right)$.

\section{DEP PRINCIPLE}

There are several types of force manipulation and separation technique, but this paper related to DEP manipulation and separation technology for ESKAPE detection. Based on the literature review, the common types of force are electrics, magnetic, optical, and both electrics \& magnetic as tabulated in Table 1 . The electric force used in this study was DEP. The DEP is a type of electrokinetic technique that can conduct contactless manipulation and separation of particles using nonuniform electric field intensity (Pethig 2017). The magnetic resonance is a type of magnetic field manipulation. This method uses the superparamagnetic particles to bind with specific targeted bacteria in the presence of external magnetic field. The superparamagnetic particles act as bio tagging material to targeted bacteria, whereas the external magnetic field can create magnetic dipole moment when exposed to the superparamagnetic material and targeted bacteria. Only the specific targeted bacteria can get through the separation channel containing seven channels with specific probes for each. These specific probes are useful for detecting and counting the number of bacteria isolated (De De Angelis et al. 2018). Another type of force is optical force. Generally, this technique uses different intensity of fluorescence with specific bio tagging material or some polymer chains to identify the targeted bacteria or bacteria. The rate of absorption and reflected fluorescence is detected by photodiode and measured to estimate the number of bacteria isolated (Renner et al. 2017; Xu et al. 2017). Lastly, the mass spectrometry invented by Leung et al. (2017) use a combination of the electric and magnetic forces. The ESKAPE sample in this technique was isolated from pure culture or biological specimen and whole cell lipids were extracted by hot ammonium isobutyrate. The lipid extracts were purified and analysed by MALDI-TOFMS (mass spectrometry). A sample in liquid formed was ionised by bombarding it with electrons. The high energy of electron beam caused the ESKAPE bacteria solution with lipid polymerised molecules to break into charged fragments and charged non-fragments. The electric and magnetic field were subjected to these ions of ESKAPE bacteria solution, which were then separated according to their mass-to-ratio. The heavier ions were not or less deflected compared to the lighter ones. Electron multiplier acts as detector of charged ions. It can differentiate the different ions based on their mass. The results of function of the mass-to-charge ratio were obtained by the signal intensity of detected ions in which the characteristics of fragmentation pattern were known by correlating the masses of an entire molecule to the identified masses.

TABLE 1. Comparative analysis for difference type's force of manipulation technique

\begin{tabular}{llll}
\hline \multicolumn{1}{c}{ Type forces } & \multicolumn{1}{c}{ Examples } & \multicolumn{1}{c}{ Operation } & \multicolumn{1}{c}{ References } \\
\hline Electrics & Dielectrophoresis & Dielectric polarity & (Pethig 2017) \\
Magnetics & Magnetic resonance & Intensity of magnetic field & (De Angelis et al. 2018) \\
Optical & Fluorescence analysis & Intensity of light & (Renner et al. 2017) \\
$\begin{array}{l}\text { Electrics and } \\
\text { magnetics }\end{array}$ & Mass spectrometer & Mass of ions & (Xu et al. 2017) \\
\hline
\end{tabular}

This study emphasizes on finding $\mathrm{f}_{\mathrm{xo}}$ from the basic formula of $\mathrm{F}_{\mathrm{DEP}}$. This enabled the differentiation and identification of the Clausius-Mossotti factor (CMF) for each ESKAPE species. The basic formula (1) of $\mathrm{F}_{\mathrm{DEP}}$ can be written as:

$$
F_{D E P}=2 \pi R^{3} \varepsilon_{m} \varepsilon_{0}\left(\frac{\varepsilon_{p}-\varepsilon_{m}}{\varepsilon_{p}+2 \varepsilon_{m}}\right) \nabla E^{2}
$$


The $\mathrm{R}$ is particles radius, the polarisation factor or CMF is $\left(\frac{\varepsilon_{p}-\varepsilon_{m}}{\varepsilon_{p}+2 \varepsilon_{m}}\right), \varepsilon_{\mathrm{m}}$ is permittivity of medium, $\varepsilon_{\mathrm{p}}$ is permittivity of particles and the is the gradient of squared electric's field strength (Gascoyne et al. 2013; Honegger \& Peyrade 2013; Pethig 2013). At the very low frequency of the current and voltage phasors are in phase (Pethig 2013). Thus, the conduction is dominance through the membrane. The conduction behaviour makes it easy for the medium to experience joule heating. Due to high conductivity, it can create bubbles in the medium. On the other hand, at very high frequency, the current phasor leads the voltage phasor by $\frac{\pi}{2} \mathrm{rad}$, making the permittivity parameter of cell more dominant compared to conductivity. High electrical charge stored in cell and medium can also cause the formation of bubbles (joule heating). At high frequency above than 100 $\mathrm{kHz}$ can reduce electrochemistry reaction (electrolysis) that caused the formation of bubbles (Adekanmbi \& Srivastava 2019). Meanwhile, stated that at frequency range from $100 \mathrm{kHz}$ to a few $\mathrm{MHz}$, the electrothermal effect is raised due to increasing frequency range, which also causes joule heating (Du \& Manoochehri 2008). This means that the input frequency above a few $\mathrm{MHz}$ can also cause the formation of bubbles. The CMF magnitude polarisation represents ESKAPE pathogen velocity. The transition CMF was from $\mathrm{P}_{\mathrm{DEP}}$ to $\mathrm{N}_{\mathrm{DEP}}$, which was divided into two regions; positive region of $\mathrm{P}_{\mathrm{DEP}}$ where particle is more polarised then medium and negative region $\left(\mathrm{N}_{\mathrm{DEP}}\right)$ where particle is less polarised then medium. Meanwhile, at the $\mathrm{f}_{\mathrm{xo}}$ point, the polarisation of $\mathrm{P}_{\mathrm{DEP}}$ or $\mathrm{N}_{\mathrm{DEP}}$ of particle was equal to polarisation of medium. The positive region, initially at low frequency, has high magnitude of $\mathrm{P}_{\mathrm{DEP}}$, represent that the velocity of ESKAPE pathogen was also high. As the input frequency increases, the magnitudes of CMF decreased together with the velocity of ESKAPE pathogen. When it reached 0 magnitude of $C M F$, the $\mathrm{P}_{D E P}$ became equal to $\mathrm{N}_{D E P}$, meaning that there was no movement of ESKAPE bacteria and velocity. The frequency increased after $\mathrm{f}_{\mathrm{xo}}$ became 0 starting from the lowest magnitude of CMF until it reached the highest magnitude of CMF. It also increased the magnitude of the ESKAPE velocity for negative regions.

\section{MATERIALS AND METHOdS}

\section{FABRICATION PROCESS}

The fabrication process technology of complementary metal-oxide-semiconductor (CMOS) is used in fabricated the Tapered Aluminium Microelectrode Arrays (TAMA) platform (Buyong et al. 2015). The plasma-enhanced chemical vapour deposition (PECVD) silicon oxide $\left(\mathrm{SiO}_{2}\right)$ is deposited about $1.15 \mu \mathrm{m}$ as an insulator on top layer of silicon substrate. Then, the physical-vapour-deposition (PVD) technique is using to deposited about $60 / 30 \mathrm{~nm}$ of a thin adhesion layer of titanium/titanium nitrite (Ti/ TiN). The PVD is using to deposited following the Ti/ TiN deposition a layer of aluminium/silicon/copper $\mathrm{Al} / \mathrm{Si} / \mathrm{Cu}(98 / 1 / 1$ wt. \%) with thickness of $4.0 \mu \mathrm{m}$. To pattern the square array structure to the $\mathrm{Al} / \mathrm{Si} / \mathrm{Cu}$ layer, photolithography with resist thickness of $4.0 \mu \mathrm{m}$ including UV cured for hardened photoresist process is performed. Lastly, by using inductive coupled plasma (ICP) etcher with advance plasma resist strip, $\mathrm{Al} / \mathrm{Si} / \mathrm{Cu}$ is being etched. The process flow of fabrication steps is presented in Figure 2(a) until 2(f).

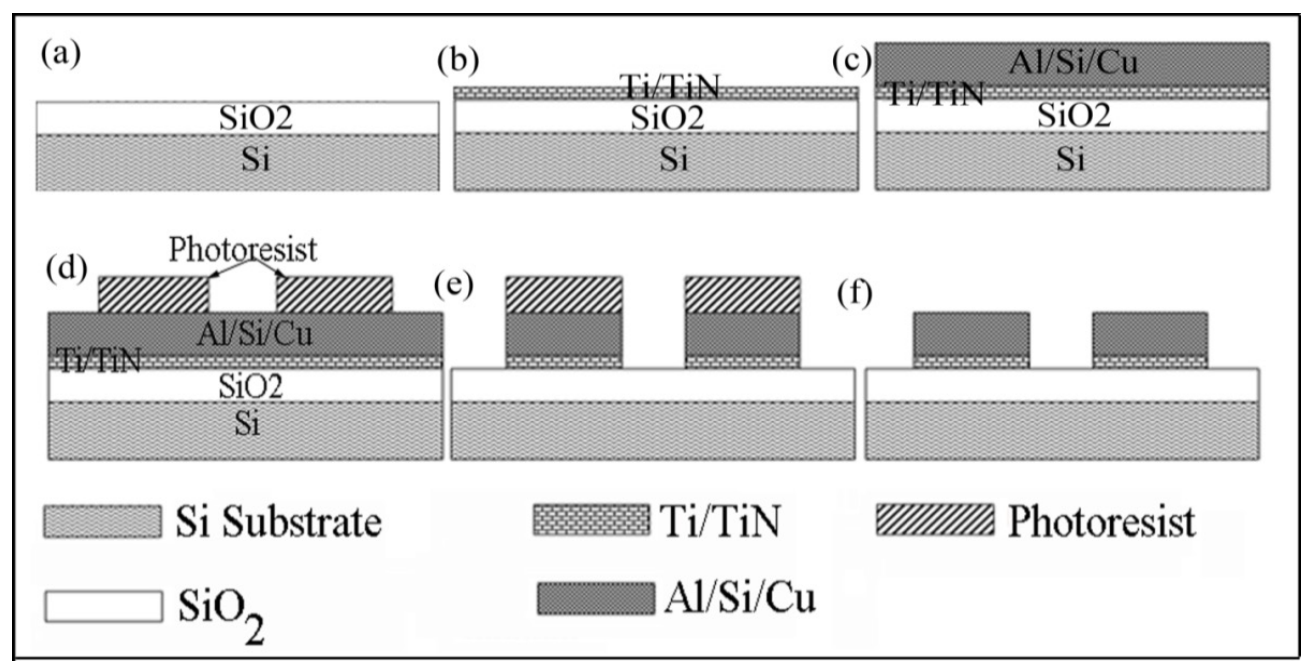

FIGURE 2. Schematic of process flow for TAMA fabrication (Buyong et al. 2019) 


\section{ESKAPE SAMPLES PREPARATION}

The ESKAPE pathogens were obtained from the Novel Antibiotic Laboratory at the Faculty of Health Sciences, Universiti Kebangsaan Malaysia Kuala Lumpur (UKMKL) in formed culture petri dish. The first step of sample preparation is started by sterilising all equipment such as wire loop and agar petri dish that contain individual colonies of ESKAPE bacteria using the Bunsen burner. The wire loop was heated up until it looks like 'red flammable' and then, the temperature was reduced in a few seconds. After that, the white spot on the agar dish was scratched directly. The white spot was gently scratched only on the surface. The flame of Bunsen burner was retained open to ensure that the environment was still in a sterilised condition while making the bacteria suspension medium. Subsequent, the tiny dot of white spot was transferred from the agar incubated dish to the test tube containing $1 \mathrm{~mL}$ DI water. The DI water was stirred with wire loop inside the test tube until all tiny white spots on the wire loop were completely dissolved. The DI water with low permittivity of $78 \mathrm{~F} \mathrm{~m}^{-1}$ and conductivity of $0.0002 \mathrm{~S} \mathrm{~m}^{-1}$ was used for medium bacteria suspension preparation to reduce the joule heating effect. The wire loop was then removed and the cap of the test tube was immediately closed. The test tube was gently shaken to ensure that the bacteria suspension was completely dissolved.

\section{ANALYTICAL MODELLING}

The analytical modelling of polarisation factors is using Maxwell-Wagner effect for CMF analysis. The analytical modelling from complex number for extraction unique identifications of ESKAPE was done using MATLAB software. The analytical modelling of ESKAPE was derived from dielectric properties of ESKAPE and medium permittivity and conductivity values. The dielectric properties of permittivity and conductivity values are defined using the $\mathrm{f}_{\mathrm{xo}}$ for all ESKAPE species.

\section{DEP EXPERIMENTAL WORK}

Based on the DEP experimental work, the physiological state of ESKAPE bacteria can be translated into dielectric properties to determine the $\mathrm{F}_{\mathrm{DEP}}, \mathrm{P}_{\mathrm{DEP}}$ or $\mathrm{N}_{\mathrm{DEP}}$ responses and the $\mathrm{f}_{\mathrm{xo}}$. Therefore, the analytical modelling CMF was validated by experimental DEP using tapered DEP microelectrode, TAMA to observe the actual of ESKAPE bacteria by observing $\mathrm{P}_{\mathrm{DEP}}, \mathrm{N}_{\mathrm{DEP}}$, and $\mathrm{f}_{\mathrm{xo}}$ responses. Determination of range $f_{x o}$ based on equation (1) use for ESKAPE bacteria detection, where the $\mathrm{f}_{\mathrm{x}}$ is related to $\mathrm{F}_{\mathrm{DEP}}$ of $\mathrm{P}_{\mathrm{DEP}}$ is equal to $\mathrm{N}_{\mathrm{DEP}}$. Once input frequency applied are increased or decreased in non-uniform electric field distribution, $\mathrm{F}_{\mathrm{DEP}}$ responses will expose to ESKAPE bacteria cause the movement at different velocity. At certain frequency range, if there is no ESKAPE bacteria movement then it is defined as $f_{x o}$.

The experimental setup consisted of microscope (STM-6 Olympus Japan), eyepiece camera (AM7025X Dino-Eye Edge), function generator (IWATSU SG-4105), micro glass covers with dimension of $20 \times 20 \mathrm{~mm}$, prober, and tapered DEP microelectrode. The micropipette was used to drop $0.2 \mu \mathrm{L}$ of ESKAPE bacteria suspension on tapered DEP microelectrode with polymide well having $2080 \times 2080 \mu \mathrm{m}$ of dimension. Micro cover glass was put on top of the DEP microelectrode to ensure that the ESKAPE bacteria droplets were properly confined. The DEP experimental setup for ESKAPE bacteria detection is illustrated in Figure 3.



FIGURE 3. The illustration of DEP experimental setup for ESKAPE detection 


\section{MEASUREMENT OF ESKAPE VELOCITY}

The measurement of ESKAPE velocity was based on video recording captured by eye-piece camera. From the video frame, the displacement of ESKAPE pathogen was identified with recorded time for velocity measurement analysis. The displacement between two points was done under condition $\mathrm{P}_{\mathrm{DEP}}$ and $\mathrm{N}_{\mathrm{DEP}}$. In detail, for the case of $\mathrm{P}_{\mathrm{DEP}}$, the displacement range was $5 \mu \mathrm{m}$ between of two microelectrode edges, which was to the top surface microelectrode. In contrast, $\mathrm{N}_{\mathrm{DEP}}$ was from top surface of microelectrode to edges in between microelectrode with the similar displacement of $5 \mu \mathrm{m}$.

\section{RESULTS AND DISCUSSION}

\section{ANALYTICAL CMF MODELLING}

Based on the analytical modelling of CMF simulation, the detection frequency range was used from 100 until $15000 \mathrm{kHz}$, showed in Figure 4. The physical differences ESKAPE bacteria produced different frequency response. This is proven by referring $\mathrm{f}_{\mathrm{xo}}$ differences for each $E S K A P E$ bacterium. Equation (1) was use to identify values of each ESKAPE CMF. The CMF calculations are based on the parameter of shape and ranges size as tabled in Table 2. The unit of round-shaped bacteria was measured in $\mu \mathrm{m}$ as diameter meanwhile for rod-shaped bacteria were measured as a dimension of length by width, also the unit in $\mu \mathrm{m}$.

TABLE 2. The ranges size/ dimension of ESKAPE pathogens

\begin{tabular}{lccl}
\hline Pathogens species & Shape & Size/Dimension in $\mu \mathrm{m}$ & \multicolumn{1}{l}{ References } \\
\hline$E F$ & Round & $\sim 0.75-0.76$ & (Lalam et al. 2015) \\
$S A$ & Round & $\sim 0.50-1.00$ & (Gnanamani et al. 2017) \\
$K P$ & Rod & $\sim 1.29 \times 0.58$ & (Rajeshwari et al. 2009) \\
$A B$ & Rod & $\sim 1.50-2.50 \times \sim 1.00-1.50$ & (Almasaudi 2018) \\
$P A$ & Rod & $\sim 2.0 \times 0.50$ & (Vater et al. 2014) \\
$E A$ & Rod & $\sim 1.45 \times 0.70$ & (Diene et al. 2013) \\
\hline
\end{tabular}

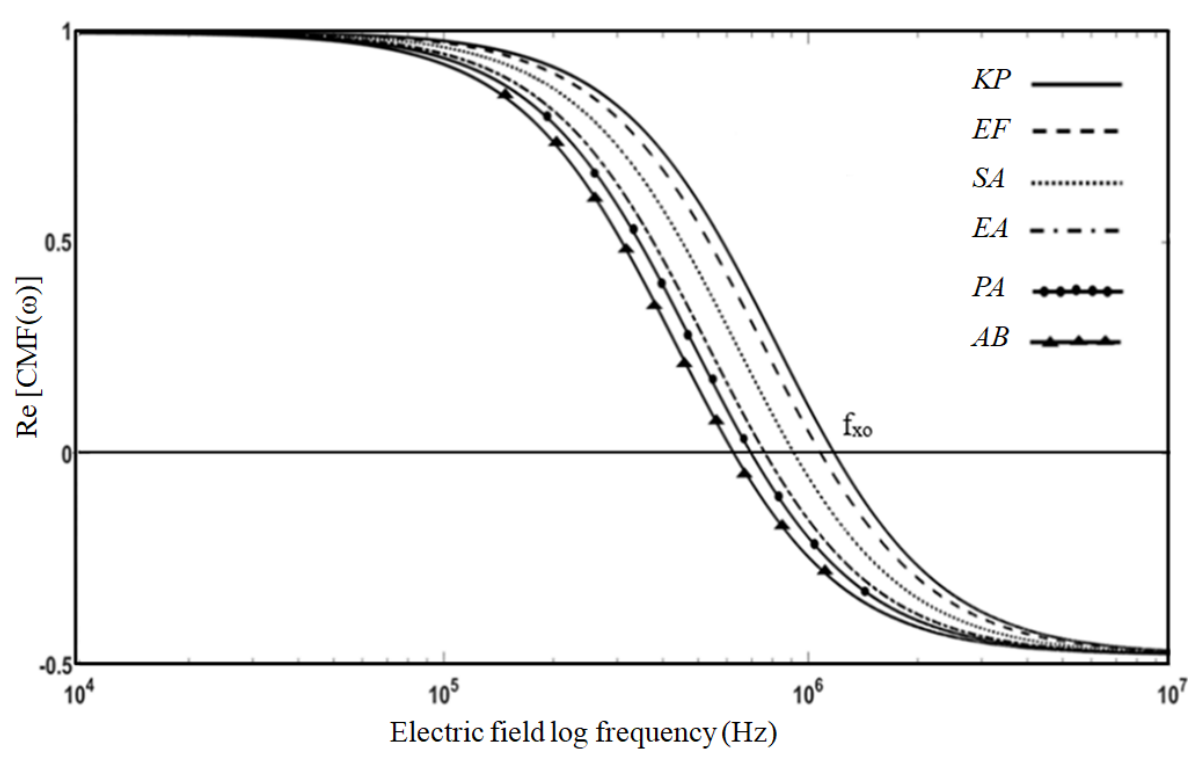

FIGURE 4. MATLAB simulation of CMF for ESKAPE bacteria 


\section{EXPERIMENTAL RESULT}

This study has successfully conducted the DEP experiment for all six species of the ESKAPE bacteria. The $\mathrm{f}_{\mathrm{xo}}$ ranges of $E F, S A, K P, A B, P A$, and $E A$ were 11000 to 11100 $\mathrm{kHz}, 6000$ to $10000 \mathrm{kHz}, 7100 \mathrm{kHz}, 6100$ to $7000 \mathrm{kHz}$, 10000 to $12000 \mathrm{kHz}$, and 1200 to $1300 \mathrm{kHz}$, respectively. Meanwhile, the $\mathrm{P}_{\mathrm{DEP}}$ range responses for $E F, S A, K P, A B$, $P A$, and $E A$ were at 900 to $10900 \mathrm{kHz}, 100$ to $5900 \mathrm{kHz}$, 100 to $7000 \mathrm{kHz}, 100$ to $6000 \mathrm{kHz}, 100$ to $9900 \mathrm{kHz}$, and 300 to $1100 \mathrm{kHz}$, respectively. For $\mathrm{N}_{\mathrm{DEP}}$ responses of $E F, S A, K P, A B, P A$, and $E A$, their input frequencies were 11200 to $15000 \mathrm{kHz}, 11000$ to $14000 \mathrm{kHz}, 7500$ to 15000 $\mathrm{kHz}, 7500$ to $10000 \mathrm{kHz}, 13000$ to $15000 \mathrm{kHz}$, and 1400 to $15000 \mathrm{kHz}$, respectively. It is proven that the tapered DEP microelectrode has the ability for detection of the ESKAPE bacteria. Based on their different sizes and shapes that formulated into $\mathrm{f}_{\mathrm{xo}}$ of CMF consisted permittivity and conductivity then represent as dielectric properties. Figure 5 shows example of $E A$ species, 5(a)-5(b) the $\mathrm{P}_{\text {DEP }}$ responses when applied $6 \mathrm{~V}_{\mathrm{p}-\mathrm{p}}$ at the $300 \mathrm{kHz}$ frequency. $\mathrm{P}_{\mathrm{DEP}}$ response occurred $E A$ species were attracted to the top surface of tapered DEP microelectrode, due high intensity of electric field at the top surface of tapered DEP microelectrode compared to in between microelectrode. Since the $E A$ species were more polarised then the medium at applied input frequency. Furthermore, Figure 5(c)-5(d) shows that $6 \mathrm{~V}_{\mathrm{p}-\mathrm{p}}$ at $5000 \mathrm{kHz}$ was identified as $\mathrm{N}_{\mathrm{DEP}}$ response. All $E A$ species were repelled to the centre of the tapered DEP microelectrode. This region has the low intensity of electric field, resulted the $E A$ species to accumulate in between the microelectrode. In this condition as applied input frequency $E A$ species were less polarised then the medium. Figure $5(\mathrm{e})-5(\mathrm{f})$ shows that input applied of $6 \mathrm{~V}_{\mathrm{p}-\mathrm{p}}$ at $1200 \mathrm{kHz}$, no movement for all $E A$ species because there was no difference in $\mathrm{F}_{\mathrm{DEP}}$. Which means that $\mathrm{P}_{\mathrm{DEP}}$ was equal to $\mathrm{N}_{\text {DEP }}$, defined as $\mathrm{f}_{\mathrm{xo}}$ for $E A$ species detection. The white arrows in Figure 5(a)-5(b) and Figure 5(c)-5(d) illustrate the movement of $E A$ bacteria when electric field was applied at initial $0 \mathrm{~s}$ to final stage $10 \mathrm{~s}$, respectively.
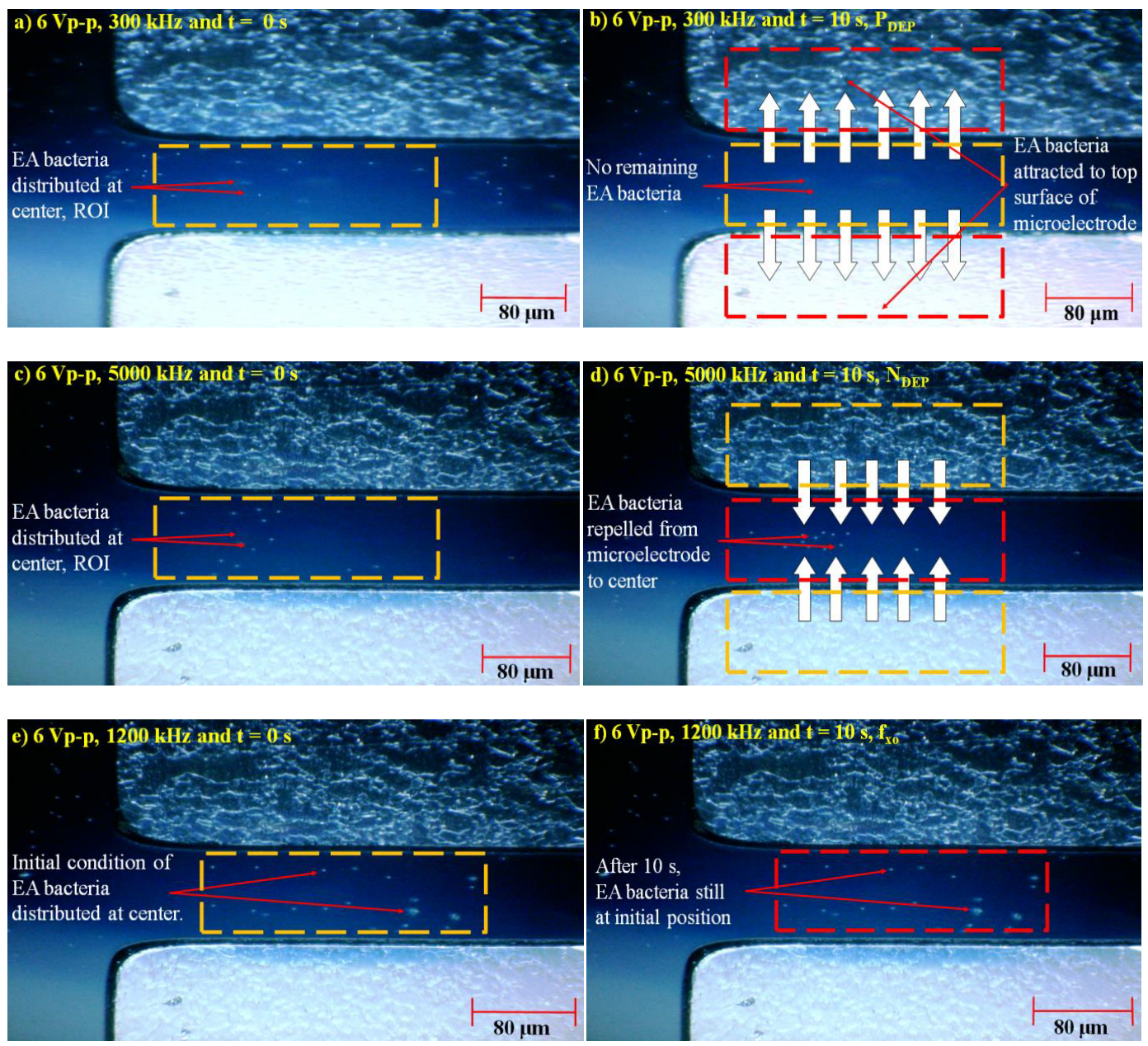

FIGURE 5. $E A$ species (a) Initial condition at $6 \mathrm{~V}_{\mathrm{p}-\mathrm{p}}$ at $300 \mathrm{kHz}$, (b) $\mathrm{P}_{D E P}$ response after $10 \mathrm{~s}$, (c) Initial condition at $6 \mathrm{~V}_{\mathrm{p}-\mathrm{p}}$ at $5000 \mathrm{kHz}$, (d) $\mathrm{N}_{\text {DEP }}$ response after $10 \mathrm{~s}$, (e) Initial condition at $6 \mathrm{~V}_{\mathrm{p} \text { - }}$ at $1200 \mathrm{kHz}$, and (f) $\mathrm{f}_{\mathrm{xo}}$ response, no movement after $10 \mathrm{~s}$ 
ANALYSIS OF ESKAPE VELOCITY

Based on the DEP experimental, the velocity against input frequency curves for ESKAPE bacteria species were constructed as shown in Figure 6(a). The EF species showed five peaks for $\mathrm{P}_{\mathrm{DEP}}$ and two peaks for $\mathrm{N}_{\mathrm{DEP}}$. The highest $\mathrm{P}_{\text {DEP }}$ velocity for $E F$ was $3.81 \mu \mathrm{m} \mathrm{s}^{-1}$ at $200 \mathrm{kHz}$ of input frequency, whereas the highest $\mathrm{N}_{\mathrm{DEP}}$ velocity was $0.45 \mu \mathrm{m} \mathrm{s}^{-1}$ at $11800 \mathrm{kHz}$. The $\mathrm{f}_{\mathrm{xo}}$ was determined when no movement of $E F$ bacteria. The $\mathrm{f}_{\mathrm{xo}}$ for $E F$ was at the range of 11000 until $11800 \mathrm{kHz}$ of input frequencies as shown in Figure 6(a). Subsequently, the $S A$ species showed two peaks for $\mathrm{P}_{D E P}$ and one peak for $\mathrm{N}_{\mathrm{DEP}}$. The highest $\mathrm{P}_{\mathrm{DEP}}$ velocity was $9.52 \mu \mathrm{m} \mathrm{s}^{-1}$ at $5000 \mathrm{kHz}$ while the highest $\mathrm{N}_{\text {DEP }}$ velocity was $19.04 \mu \mathrm{m}$ at $14000 \mathrm{kHz}$. The $\mathrm{f}_{\mathrm{xo}}$ for $S A$ species ranging from 6000 until $10000 \mathrm{kHz}$ is as shown in Figure 6(a). The $K P$ showed five peaks for $\mathrm{P}_{\mathrm{DEP}}$ and two peaks for $\mathrm{N}_{D E P}$. The highest $\mathrm{P}_{\text {DEP }}$ velocity was $4.39 \mu \mathrm{m} \mathrm{s}^{-1}$ at $2000 \mathrm{kHz}$ while the highest $\mathrm{N}_{\text {DEP }}$ velocity was $0.24 \mu \mathrm{m}$ $\mathrm{s}^{-1}$ at $7200 \mathrm{kHz}$. The $\mathrm{f}_{\mathrm{xo}}$ was at $7100 \mathrm{kHz}$ of input frequency as in Figure 6(a). The $A B$ species showed five peaks for $\mathrm{P}_{D E P}$ and one peak for $\mathrm{N}_{D E P}$. The highest $\mathrm{P}_{\mathrm{DEP}}$ velocity was $5.85 \mu \mathrm{m} \mathrm{s}^{-1}$ at $3000 \mathrm{kHz}$ while the highest $\mathrm{N}_{\text {DEP }}$ velocity was $0.40 \mu \mathrm{m} \mathrm{s}^{-1}$ at $7500 \mathrm{kHz}$. The $\mathrm{f}_{\text {xo }}$ of $A B$ was ranged from 6100 until $7000 \mathrm{kHz}$. The $A B$ curve is displayed in Figure 6(a). The $P A$ species demonstrated four peaks for $\mathrm{P}_{\mathrm{DEP}}$ and one peak for $\mathrm{N}_{\mathrm{DEP}}$. The highest $\mathrm{P}_{\mathrm{DEP}}$ velocity was $12.4 \mu \mathrm{m} \mathrm{s}^{-1}$ at $3000 \mathrm{kHz}$ and the highest $\mathrm{N}_{\mathrm{DEP}}$ velocity was $0.28 \mu \mathrm{m} \mathrm{s}^{-1}$ at $13000 \mathrm{kHz}$. The $\mathrm{f}_{\mathrm{xo}}$ for $P A$ was ranged from
10000 until $12000 \mathrm{kHz}$ as shown in Figure 6(a). Lastly, the $E A$ species displayed one peak for $\mathrm{P}_{\mathrm{DEP}}$ and one peak for $\mathrm{N}_{\mathrm{DEP}}$. The highest $\mathrm{P}_{\mathrm{DEP}}$ velocity was $80 \mu \mathrm{m} \mathrm{s}^{-1}$ at 1100 $\mathrm{kHz}$ and the highest $\mathrm{N}_{\mathrm{DEP}}$ velocity was $40 \mu \mathrm{m} \mathrm{s}^{-1}$ at range frequency of 8000 until $10000 \mathrm{kHz}$. Meanwhile, their $\mathrm{f}_{\mathrm{xo}}$ frequency was ranged from 1200 until $1300 \mathrm{kHz}$. The $E A$ velocity curve is as shown in Figure 6(a). From further analysis of velocity ESKAPE bacteria we can produce the secondary data and plotted the frequencies range for $\mathrm{P}_{\mathrm{DEP}}$ and $\mathrm{N}_{\mathrm{DEP}}$ in Figure 6(b). The $\mathrm{P}_{\mathrm{DEP}}$ response for $E F$ species is range in 100 until $11000 \mathrm{kHz}$ and for $\mathrm{N}_{\mathrm{DEP}}$ is range in 11800 until $15000 \mathrm{kHz}$. The $S A$ species for $\mathrm{P}_{\mathrm{DEP}}$ is range in 100 until $6000 \mathrm{kHz}$ meanwhile for $\mathrm{N}_{\mathrm{DEP}}$ is range in 10000 until $14000 \mathrm{kHz}$. The $K P$ species for $\mathrm{P}_{\mathrm{DEP}}$ is range in 100 until $7000 \mathrm{kHz}$ but for $\mathrm{N}_{\text {DEP }}$ is range in 7200 until 15000 $\mathrm{kHz}$. The $A B$ species for $\mathrm{P}_{\mathrm{DEP}}$ is range in 100 until 6100 $\mathrm{kHz}$. Meanwhile, for $\mathrm{N}_{\mathrm{DEP}}$ response is range in 7000 until $10000 \mathrm{kHz}$. The $P A$ species for $\mathrm{P}_{\mathrm{DEP}}$ is range in 100 until $10000 \mathrm{kHz}$ and their $\mathrm{N}_{\mathrm{DEP}}$ response is range in 12000 until $15000 \mathrm{kHz}$. Then, lastly the $E A$ species for $\mathrm{P}_{\mathrm{DEP}}$ is range in 100 until $1100 \mathrm{kHz}$. Meanwhile, for their $\mathrm{N}_{\mathrm{DEP}}$ response is range in 1300 until $15000 \mathrm{kHz}$. Figure 6(b) is illustrated the working frequency range for $\mathrm{P}_{\mathrm{DEP}}$ and $\mathrm{N}_{\mathrm{DEP}}$ by leftright arrows. The coloured box was showed the $\mathrm{f}_{\mathrm{xo}}$ ranges for each ESKAPE species. Based on the velocity curve in Figure 6(b), a step of determining a $\mathrm{f}_{\mathrm{xo}}$ of two or more ESKAPE bacteria having over-lapping dielectrophoretic frequency responses, $\mathrm{f}_{\text {хо }}$ was defined. In the case of $S A$
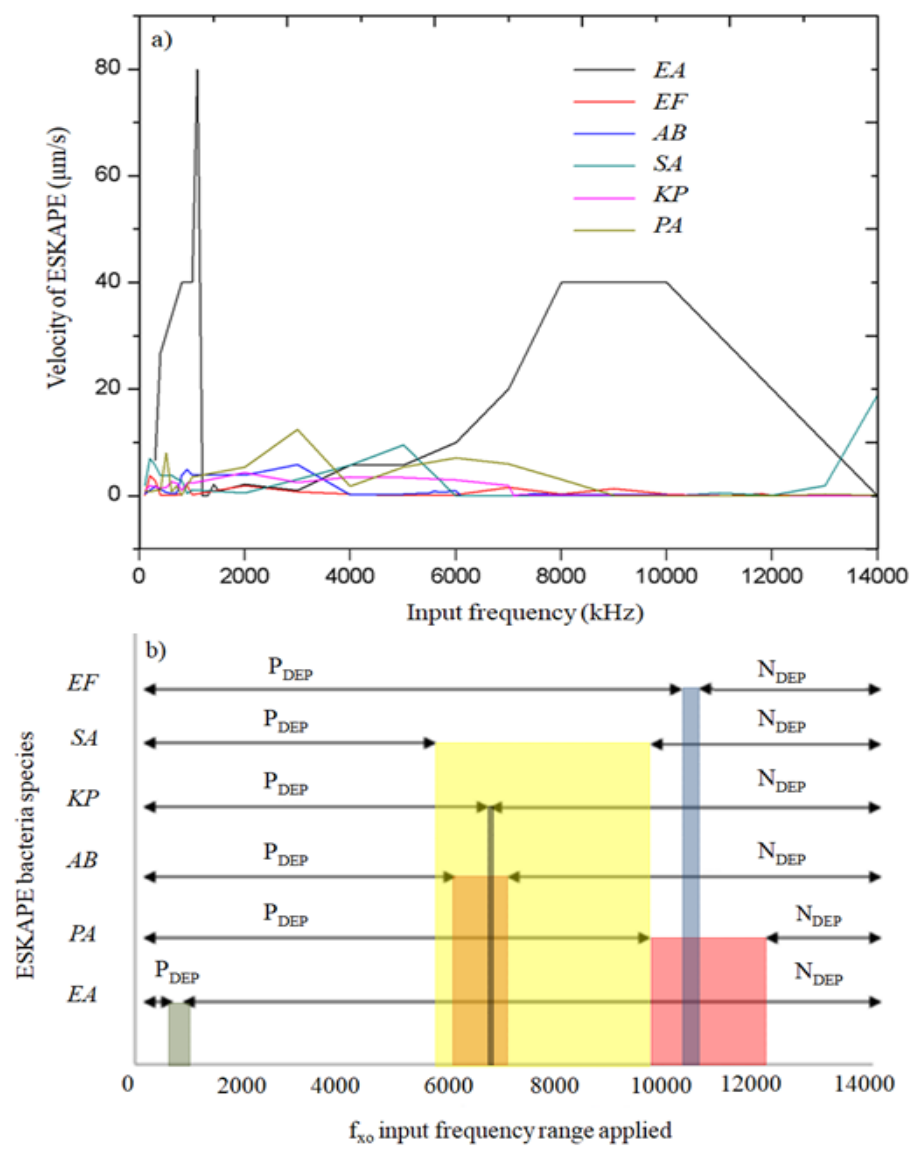

FIGURE 6. Experimental results for ESKAPE (a) Velocity of ESKAPE versus input frequency applied and (b) ESKAPE species versus $\mathrm{f}_{\mathrm{x}}$ detection of frequency range 
and $K P$, the detection $K P$ was easier because there was only one point of $\mathrm{f}_{\mathrm{xo}}$. However, for $S A$ species there was a wide range of DEP crossover between 6000 and 10000 $\mathrm{kHz}$. This is due to different physical size and shape of $S A$ and $K P$, thus, different range of $\mathrm{f}_{\mathrm{xo}}$ was produced. The $S A$ species physically have round shape-grape arrangement (Gnanamani et al. 2017) and a wide frequency range as shown in this study. Based on the $S A$ species bacteria cell arrangement, the total surface area was increased due to the grape-shaped arrangement. Thus, the equation of $\mathrm{F}_{\mathrm{DEP}}$ proved that the dielectrics values were also increased. In contrast, the $K P$ species have a rod shape but exist in individual arrangement (Rajeshwari et al. 2009). This has caused a low surface area compared to that of $S A$ species. The dielectric values of $K P$ were also decreased, which was proved by DEP experiment showing only one $f_{x o}$ point at $7100 \mathrm{kHz}$. Furthermore, in this study three ESKAPE species namely $S A, K P$, and $A B$ were overlapped at certain $\mathrm{f}_{\mathrm{xo}}$ range points $(7100 \mathrm{kHz}$ and 6100 to 7000 $\mathrm{kHz}$ ) as showed in Figure 6(b). The smallest range of the black box of $K P$, the medium of range of the brown box of $A B$ were intercepted in bigger yellow box of $S A$ due to bigger range of $\mathrm{f}_{\mathrm{x}}$. Detection these three ESKAPE species using the lowest and highest ranges of $\mathrm{f}_{\mathrm{xo}}$ were utilised by identified the uniqueness of their own different of dielectric properties for ESKAPE detection species. Similar method also is implemented to another three of ESKAPE species namely $P A$ and $E F$ were overlapped at certain $\mathrm{f}_{\text {xo }}$ also $E A$ species.

\section{DISCUSSION}

The shape and size of each ESKAPE species was not identical. The average size of ESKAPE species was below $2 \mu \mathrm{m}$. In fact, range size of each ESKAPE species was between 1 and $2 \mu \mathrm{m}$. Therefore, based on the shape and size produced different dielectric values resulted unique $\mathrm{f}_{\mathrm{xo}}$ for rapid ESKAPE bacteria detection method using tapered DEP microelectrodes via $\mathrm{f}_{\mathrm{xo}}$ analysis. The results of maximum and average speed for each ESKAPE bacteria were listed in Table 3 .

TABLE 3. Speed of movement and average speed of ESKAPE pathogens

\begin{tabular}{|c|c|c|c|}
\hline \multirow{2}{*}{ Species } & \multicolumn{2}{|c|}{ Speed of movement $\left(\mu \mathrm{m} \mathrm{s}^{-1}\right)$} & \multirow{2}{*}{ Average of speed $\left(\mu \mathrm{m} \mathrm{s}^{-1}\right)$} \\
\hline & $P_{\mathrm{DEP}}(\max )$ & $N_{\text {DEP }}(\max )$ & \\
\hline$E F$ & 3.81 & 0.45 & 2.13 \\
\hline$S A$ & 9.52 & 19.04 & 14.28 \\
\hline$K P$ & 4.39 & 0.24 & 2.31 \\
\hline$A B$ & 5.85 & 0.40 & 3.13 \\
\hline$P A$ & 12.4 & 0.28 & 6.34 \\
\hline$E A$ & 80 & 40 & 60 \\
\hline
\end{tabular}

The higher speed movement of $\mathrm{F}_{\mathrm{DEP}}$ response was $E A$ species, $80 \mu \mathrm{m} \mathrm{s}^{-1}$ for $P_{\mathrm{DEP}}$, and $40 \mu \mathrm{m} \mathrm{s}^{-1}$ for $\mathrm{N}_{\mathrm{DEP}}$ with an average speed of $60 \mu \mathrm{m} \mathrm{s}^{-1}$. Meanwhile, the lower speed movement is $E F$ species with $3.81 \mu \mathrm{m} \mathrm{s}^{-1}$ for $\mathrm{P}_{\text {DEP }}$ and $0.45 \mu \mathrm{m} \mathrm{s}^{-1}$ for $\mathrm{N}_{\text {DEP }}$ with an average speed of $2.13 \mu \mathrm{m}$ $\mathrm{s}^{-1}$. The $E F$ and $S A$ bacteria have round-shaped and the smallest sizes compared to $K P, A B, P A$, and $E A$ species. However, $E F$ and $S A$ velocities are lower because of the arrangement in colonies such as grape-like clusters and pair-chains. It makes heavier $\mathrm{F}_{\mathrm{DEP}}$ for levitated these two species of bacteria $E F$ and $S A$. The rest of the bacteria for four species $K P, A B, P A$, and $E A$ are exited in individual orientation, not in colony form. In general, $K P, A B, P A$, and $E A$ have rod-shaped with ranged dimensions were $\sim$
1.29 to $2.0 \mu \mathrm{m}$ in length by $\sim 0.50$ to $1.50 \mu \mathrm{m}$ in width. It was a larger range of sizes compared to $P A$ and $S A$ species. It also means that $K P, A B$, and $P A$ have heavier $\mathrm{F}_{\mathrm{DEP}}$ for levitate these kinds of bacteria. Special case for $E A$, there has the addition structure coved at the surface of the rod, it called pilus and flagella. It was like a hair structure, used for bacteria swimming and reproduction. The EA species existed in individual but the pilus and flagella make the bacteria attached to each other when the electric field applied in DEP experimental. Its surface area increases and make heavier. With the increasing value of frequencies, the effectiveness of $\mathrm{F}_{\mathrm{DEP}}$ also increases then it can levitate the $E A$ bacteria attached each with a larger surface area. Initially, it has low momentum due to low 
frequencies range but after it achieved maximum $\mathrm{F}_{\mathrm{DEP}}$ effectiveness at $1100 \mathrm{kHz}$ of $\mathrm{P}_{\text {DEP }}$ and 8000 until 10000 $\mathrm{kHz}$ of $\mathrm{N}_{\mathrm{DEP}}$. Therefore, it generated the high momentum and then produced the maximum velocity of $80 \mu \mathrm{m} \mathrm{s}^{-1}$ of $\mathrm{P}_{\text {DEP }}$ and $40 \mu \mathrm{m} \mathrm{s}^{-1}$ of $\mathrm{N}_{\text {DEP }}$, respectively. This proved each ESKAPE bacteria has a unique morphology that influenced their dielectric properties due to different shapes, sizes and arrangements. Meaning that when we are increasing or decreasing the input frequency value, this resulted in the differences of $\mathrm{F}_{\mathrm{DEP}}$ responses based on each of ESKAPE dielectric properties. The experimental DEP result indicated that only $E A$ species have the different $\mathrm{f}_{\mathrm{xo}}$ range from 1200 until $1300 \mathrm{kHz}$ compared to that of the other five species. This means that there was no intersection to other $\mathrm{f}_{\mathrm{xo}}$ ranges of other five species ESKAPE. The $P A$ species have $\mathrm{f}_{\mathrm{xo}}$ range of 10000 to $12000 \mathrm{kHz}$, which intercepted $\mathrm{f}_{x o} S A$ and $E F$ at $10000 \mathrm{kHz}$ and 11000 to 11200 $\mathrm{kHz}$, respectively. The $S A$, $\mathrm{f}_{\mathrm{xo}}$ also intercepted $A B$ at range of 6100 to $7000 \mathrm{kHz}$. The $S A$ and $K P$ were intercepted at $7100 \mathrm{kHz}$. Therefore, the species detection of mixtures for $E F$ and $P A$ species utilizes the maximum range of $\mathrm{f}_{\mathrm{xo}}$ was used for $E F$ followed by the minimum $\mathrm{f}_{\mathrm{xo}}$ range for $P A$. Meanwhile for $S A$ species detection, maximum $\mathrm{f}_{\mathrm{xo}}$ was used. The $E A$ species showed no intersection of $\mathrm{f}_{\mathrm{xo}}$ to another five species of ESKAPE, suggesting that their $\mathrm{f}_{\mathrm{xo}}$ range can be used directly as in Figure 6(b). The detecting $A B$ and $K P$ species was quiet challenging as their $\mathrm{f}_{\mathrm{xo}}$ ranges overlapped to the huge $S A \mathrm{f}_{\mathrm{xo}}$ range. Overall, DEP method is potentially and suitable for ESKAPE species detection method. However, further investigation on similar physical size and the $\mathrm{f}_{\mathrm{xo}}$ need to be explore. Table 4 was listed and summarized all the ESKAPE species detection technique based on our discussions in the introduction section. The comparison DEP result was included the detection method, time constrain, and advantages and disadvantages.

TABLE 4. The comparison of current technologies used for ESKAPE bacteria detection with tapered DEP microelectrode technique

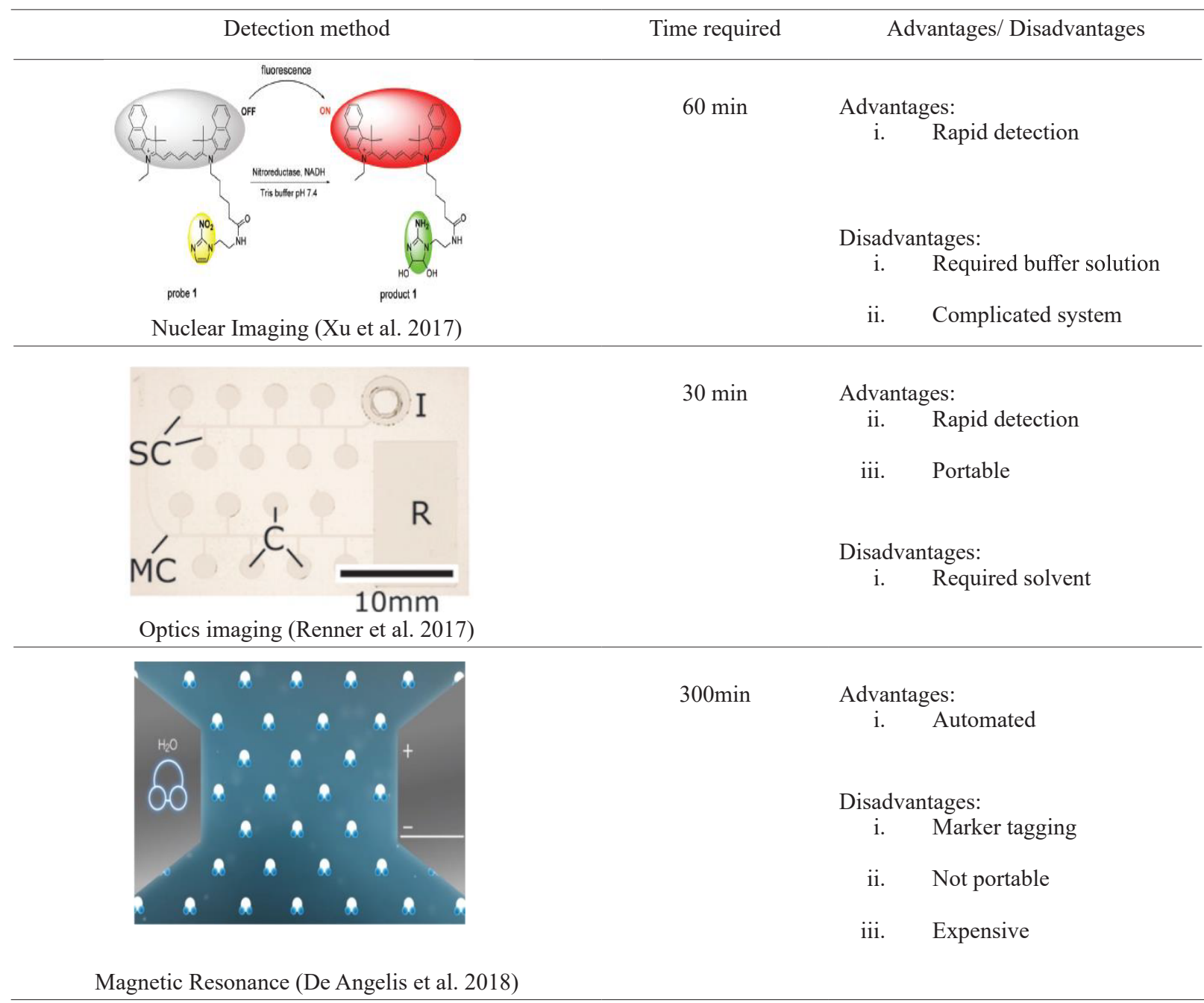




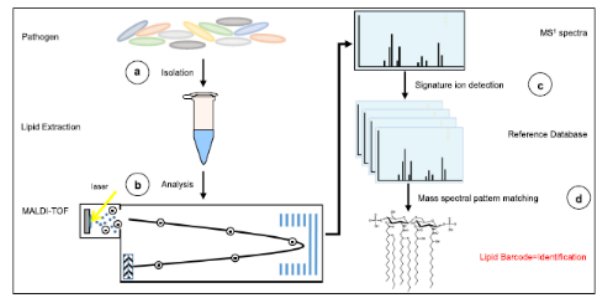

Real time detection Advantages:

i. Rapid detection

Disadvantage:

i. Required Solvent

ii. Not portable

Electric and Magnetic (Leung et al. 2017)

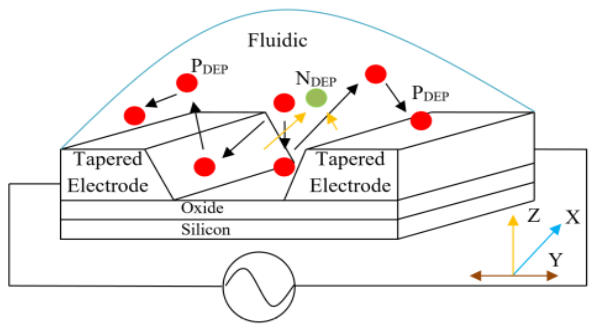

DEP (Buyong et al. 2019)
Real time detection Advantages:

i. Rapid detection

ii. No labelling

Disadvantages:

i. $\quad$ Required AC field

ii. Joule Heating

iii. Electrolysis

\section{CONCLUSION}

The DEP detection based on shape and size of ESKAPE bacteria were approximately average from 1 to $2 \mu \mathrm{m}$ resulted in the $\mathrm{f}_{\mathrm{xo}}$ overlap. Therefore, there was a wide frequency range observed due to different geometrical size and shapes of round and rod among the ESKAPE bacteria. The utilization of $\mathrm{f}_{\mathrm{xo}}$ has overlapping differences, which have the potential to formulate the detection based on the lowest and highest ranges of $\mathrm{f}_{\mathrm{xo}}$ for each ESKAPE bacteria. Thus, the $\mathrm{f}_{\mathrm{xo}}$ were defined as potential solution for rapid ESKAPE bacteria detection method using tapered DEP microelectrodes via $\mathrm{f}_{\mathrm{xo}}$ analysis.

\section{ACKNOWLEDGEMENTS}

The author would like to acknowledge with gratitude the sponsor of Geran Galakan Penyelidik Muda (GGPM2017-028), AKU254: HICOE (FASA2) Artificial Kidney Research Fund from the Ministry of Higher Education, Malaysia, Dana Cabaran Perdana (DCP-2017-003/3) and Fundamental Research Grant Scheme (FRGS/1/2017/ TK04/UKM/02/14).

\section{REFERENCES}

Abd Samad, M.I., Buyong, M.R., Kim, S.S. \& Majlis, B.Y. 2019. Dielectrophoresis velocities response on tapered electrode profile: Simulation and experimental. Microelectronics International 36: 45-53.

Adekanmbi, E.O. \& Srivastava, S.K. 2019. Applications of electrokinetics and dielectrophoresis on designing chip-based disease diagnostic platforms. In Bio-Inspired Technology. https://www.intechopen.com/books/bio-inspired-technology/ applications-of-electrokinetics-and-dielectrophoresis-ondesigning-chip-based-disease-diagnostic-pla. DOI: 10.5772/ intechopen.82637.

Almasaudi, S.B. 2018. Acinetobacter spp. as nosocomial pathogens: Epidemiology and resistance features. Saudi Journal of Biological Sciences 25(3): 586-596.

Brooks, L.E., Ul-Hasan, S., Chan, B.K. \& Sistrom, M.J. 2018. Quantifying the evolutionary conservation of genes encoding multidrug efflux pumps in the ESKAPE pathogens to identify antimicrobial drug targets. Msystems 3(3): 1-9.

Buyong, M.R., Kayani, A.A., Hamzah, A.A. \& Majlis, B.Y. 2019. Dielectrophoresis manipulation: Versatile lateral and vertical mechanisms. Biosensors 9(30): 1-26.

Buyong, M.R., Larki, F., Faiz, M.S., Hamzah, A.A., Yunas, J. \& Majlis, B.Y. 2015. Tapered aluminium microelectrode array for improvement of dielectrophoresis-based particle manipulation. Sensors 15(5): 10973-10990.

Cha, S.H., Kang, S.H., Lee, Y.J., Kim, J.H., Ahn, E.Y., Park, Y. \& Cho, S. 2019. Fabrication of nanoribbons by dielectrophoresis assisted cold welding of gold nanoparticles on mica substrate. Scientific Reports 9(1): 1-12.

D’Amico, L., Ajami, N.J., Adachi, J.A., Gascoyne, P.R. \& Petrosino, J.F. 2017. Isolation and concentration of bacteria from blood using microfluidic membraneless dialysis and dielectrophoresis. Lab on a Chip 17(7): 1340-1348.

De Angelis, G., Posteraro, B., De Carolis, E., Menchinelli, G., Franceschi, F., Tumbarello, M., De Pascale, G., Spanu, T. \& Sanguinetti, M. 2018. T2 Bacteria magnetic resonance assay for the rapid detection of ESKAPEc pathogens directly in whole blood. Journal of Antimicrobial Chemotherapy 73(suppl_4): iv20-iv26. 
Diene, S.M., Merhej, V., Henry, M., El Filali, A., Roux, V., Robert, C., Azza, S., Gavory, F., Barbe, V., La Scola, B. \& Raoult, D. 2013. The rhizome of the multidrug-resistant Enterobacter aerogenes genome reveals how new 'killer bugs' are created because of a sympatric lifestyle. Molecular Biology and Evolution 30(2): 369-383.

Du, E. \& Manoochehri, S. 2008. Electrohydrodynamicmediated dielectrophoretic separation and transport based on asymmetric electrode pairs. Electrophoresis 29(24): 5017-5025.

Gascoyne, P.R., Shim, S., Noshari, J., Becker, F.F. \& Stemke, H.K. 2013. Correlations between the dielectric properties and exterior morphology of cells revealed by dielectrophoretic field-flow fractionation. Electrophoresis 34(7): 1042-1050.

Gnanamani, A., Hariharan, P. \& Paul-Satyaseela, M. 2017. Staphylococcus aureus: Overview of bacteriology, clinical diseases, epidemiology, antibiotic resistance and therapeutic approach. Frontiers in Staphylococcus aureus 2017: 4-28.

González-Bello. C. 2017. Antibiotic adjuvants - a strategy to unlock bacterial resistance to antibiotics. Bioorganic \& Medicinal Chemistry Letters 27(18): 4221-4228.

Honegger, T. \& Peyrade, D. 2013. Comprehensive analysis of alternating current electrokinetics induced motion of colloidal particles in a three-dimensional microfluidic chip. Journal of Applied Physics 113(19): 194702.

Jamaludin, N.M.A., Buyong, M.R., Rahim, M.K., Hamzah, A.A., Mailis, B.Y. \& Bais, B. 2018. Dielectrophoresis: Characterization of triple-negative breast cancer using Clausius-Mossotti factor. In 2018 IEEE International Conference on Semiconductor Electronics (ICSE) IEEE. pp. 85-88.

Karlowsky, J.A., Hoban, D.J., Hackel, M.A., Lob, S.H. \& Sahm, D.F. 2017. Antimicrobial susceptibility of gram-negative ESKAPE pathogens isolated from hospitalized patients with intra-abdominal and urinary tract infections in AsiaPacific countries: SMART 2013-2015. Journal of Medical Microbiology 66(1): 61-69.

Kikkeri, K., Breazeal, M.V.R., Ren, X., Pruden, A. \& Agah, M. 2018. A monolithic dielectrophoresis chip with impedimetric sensing for assessment of pathogen viability. Journal of Microelectromechanical Systems 27(5): 810-817.

Lalam, C., Tantravahi, S. \& Petla, N. 2015. Identification and characterization of Enterococcus feacium (MCC-2729) with antimicrobial and abiotic stress tolerance properties. International Journal of Current Microbiology and Applied Science 4(8): 309-322.

Leung, L.M., Fondrie, W.E., Doi, Y., Johnson, J.K., Strickland, D.K., Ernst, R.K. \& Goodlett, D.R. 2017. Identification of the ESKAPE pathogens by mass spectrometric analysis of microbial membrane glycolipids. Scientific Reports 7(1): 1-10.

Mohammad, K., Buchanan, D.A., Braasch, K., Butler, M. \& Thomson, D.J. 2017. CMOS single cell dielectrophoresis cytometer. Sensors and Actuators B: Chemical 249(2012): 246-255.

Pethig, R.R. 2017. Dielectrophoresis: Theory, Methodology and Biological Applications. ${ }^{\text {st }}$ ed. London, Ontario: John Wiley \& Sons. Inc. pp. 253-254.
Pethig, R. 2013. Dielectrophoresis: An assessment of its potential to aid the research and practice of drug discovery and delivery. Advanced Drug Delivery Reviews 65(11-12): 1589-1599.

Phoon, H.Y., Hussin, H., Hussain, B.M., Lim, S.Y., Woon, J.J., Er, Y.X. \& Thong, K.L. 2018. Distribution, genetic diversity and antimicrobial resistance of clinically important bacteria from the environment of a tertiary hospital in Malaysia. Journal of Global Antimicrobial Resistance 14(2018): 132-140.

Rani, F.M., Rahman, N.I.A., Ismail, S., Alattraqchi, A.G., Cleary, D.W., Clarke, S.C. \& Yeo, C.C. 2017. Acinobacter spp. infections in Malaysia: A review of antimicrobial resistance trends, mechanisms and epidemiology. Frontiers in Microbiology 8(2017): 1-13.

Rahim, M.K.A., Buyong, M.R., Jamaludin, N.M.A., Hamzah, A.A., Siow, K.S. \& Majlis, B.Y. 2018. Characterization of permittivity and conductivity for ESKAPE pathogens detection. IEEE International Conference on Semiconductor Electronics (ICSE). pp. 132-135.

Rajeshwari, H., Nagveni, S., Oli, A., Parashar, D. \& Chandrakanth, K.R. 2009. Morphological changes of Klebsiellapneumoniae in response to cefotaxime: A scanning electron microscope study. World Journal of Microbiology and Biotechnology 25(2009): 2263-2266.

Renner, L.D., Zan, J., Hu, L.I., Martinez, M., Resto, P.J., Siegel, A.C., Torres, C., Hall, S.B., Slezak, T.R., Nguyen, T.H. \& Weibel, D.B. 2017. Detection of ESKAPE bacterial pathogens at the point of care using isothermal DNA-based assays in a portable degas-actuated microfluidic diagnostic assay platform. Applied and Environmental Microbiology 83(4): e02449.

Sadeghian, H., Hojjat, Y. \& Soleimani, M. 2017. Interdigitated electrode design and optimization for dielectrophoresis cell separation actuators. Journal of Electrostatics 86: 41-49.

Santajit, S. \& Indrawattana, N. 2016. Mechanisms of antimicrobial resistance in ESKAPE pathogens. BioMed Research International 2016: 2475067.

Shirmohammadli, V. \& Manavizadeh, N. 2018. Numerical modeling of cell trajectory inside a dielectrophoresis microdevice designed for breast cancer cell screening. IEEE Sensors Journal 18(20): 8215-8222.

Siebman, C., Velev, O. \& Slaveykova, V. 2018. Probing contaminant-induced alterations in chlorophyll fluorescence by AC-dielectrophoresis-based 2D-algal array. Biosensors 8(1): $2-8$

Vater, S.M., Weiße, S., Maleschlijski, S., Lotz, C., Koschitzki, F., Schwartz, T., Obst, U. \& Rosenhahn, A. 2014. Swimming behavior of Pseudomonas aeruginosa studied by holographic 3D tracking. PloS ONE 9(1): e87765.

Xu, S., Wang, Q., Zhang, Q., Zhang, L., Zuo, L., Jiang, J.D. \& Hu, H.Y. 2017. Real time detection of ESKAPE pathogens by a nitroreductase-triggered fluorescence turn-on probe. Chemical Communications 53(81): 11177-11180.

Yunus, F.W., Buyong, M.R., Yunas, J., Majlis, B.Y. \& Hamzah, A.A. 2019. 3-dimensional electric field distributions of castellated and straight dielectrophoresis electrodes for cell separation. Sains Malaysiana 48(6): 1239-1249.

Yunus, F.W., Hamzah, A.A., Norzin, M.S., Buyong, M.R., Yunas, J. \& Majlis, B.Y. 2018. Dielectrophoresis: Iron deficient 
anemic red blood cells for artificial kidney purposes. IEEE International Conference on Semiconductor Electronics (ICSE). pp. 5-8.

Muhammad Khairulanwar Abdul Rahim*, Nur Mas Ayu Jamaludin, Azrul Azlan Hamzah \& Muhamad Ramdzan Buyong Institute of Microengineering and Nanoelectronics (IMEN) Universiti Kebangsaan Malaysia

43600 UKM Bangi, Selangor Darul Ehsan

Malaysia
Jacinta Santhanam

Faculty of Health Sciences

Universiti Kebangsaan Malaysia

50300 Kuala Lumpur, Federal Territory

Malaysia

*Corresponding author; email: muhdramdzan@ukm.edu.my

Received: 2 June 2020

Accepted: 15 July 2020 